\title{
Synthesis and characterization of PZT 52/48 ceramics without additives througt nanomertric powder
}

\author{
Síntese e caracterização de cerâmicas \\ PZT 52/48 sem aditivos por meio \\ de pó nanométrico
}

Jaime Alberto Sanchez Caceres ${ }^{1}$, Carlos Augusto Carlos Passos ${ }^{1}$, João Victor Soares Chagas ${ }^{1}$

\footnotetext{
${ }^{1}$ Federal University of Espírito Santo, C.P.: 369, CEP: 13560-970, Vitória, Espírito Santo, Brazil. e-mail: jcaceres.vix@gmail.com, carlosaugustocp@gmail.com, jota.vitor94@gmail.com
}

\begin{abstract}
Lead zirconatetitanate solid solutions, $\mathrm{Pb}\left(\mathrm{Zr}_{1-\mathrm{x}} \mathrm{Ti}_{\mathrm{x}}\right) \mathrm{O}_{3}-\mathrm{PZT}$, are widely recognized for representing a special group of ferroelectric materials with various potential applications in electroceramics and (micro)electronic devices. The PZT ceramics is produced by solid state reaction (conventional route) and temperatures frequently above $1200{ }^{\circ} \mathrm{C}$. As a consequence, the cost of ceramic product is expensive. Herein, we present the synthesis and processing conditions of PZT52/48 $(\mathrm{x}=0.48)$ ceramics in which it was possible to lower the sintering temperature down to around $900^{\circ} \mathrm{C}$. We have applied a route for PZT52/48 obtaining ferroelectric ceramics through sintering of nanometric powders prepared by the polymeric precursor synthesis method (modified Pechini's method). The sintering was achieved with a temperature of $900^{\circ} \mathrm{C}$ for 2 hours and the samples got $96 \%$ of their theoretical density and $1.3 \mu \mathrm{m}$ mean grain size. The electrical permittivity of the ceramic plates, studied by impedance spectroscopy, presented Curie temperature around $390{ }^{\circ} \mathrm{C}$. Ferroelectric hysteresis measurements revealed that the remnant polarization is $3.2 \mu \mathrm{C} / \mathrm{cm}^{2}$ and coercive field is $10 \mathrm{kV} / \mathrm{cm}$ at $60 \mathrm{~Hz}$. All results and characterizations have shown that the PZT samples obtained with the polymeric route are efficient as the ones prepared in the conventional SSR protocol.
\end{abstract}

Keywords: PZT nanometric powder, Low temperature sintering, Dielectric properties, Ferroelectric hysteresis

\section{RESUMO}

As soluções sólidas de titanato de zirconato de chumbo, $\mathrm{Pb}\left(\mathrm{Zr}_{1-\mathrm{x}} \mathrm{Ti}_{\mathrm{x}}\right) \mathrm{O}_{3}-\mathrm{PZT}$, são amplamente reconhecidas por representar um grupo especial de materiais ferroelétricos com várias aplicações potenciais em eletrocerâmica e (micro) dispositivos eletrônicos. A cerâmica PZT é produzida por reação em estado sólido (via convencional) e temperaturas frequentemente acima de $1200{ }^{\circ} \mathrm{C}$. Como consequiência, o custo do produto cerâmico é caro. Apresentamos aqui as condições de síntese e processamento da cerâmica PZT 52/48 (x = 0,48), na qual foi possível reduzir a temperatura de sinterização para cerca de $900{ }^{\circ} \mathrm{C}$. Aplicamos uma rota para a obtenção de cerâmica ferroelétrica PZT52/48 através da sinterização de pós nanométricos preparados pelo método de síntese de precursores poliméricos (método de Pechini modificado). A sinterização foi realizada a uma temperatura de $900^{\circ} \mathrm{C}$ por 2 horas e as amostras obtiveram $96 \%$ de sua densidade teórica e tamanho médio de grão de $1,3 \mu \mathrm{m}$. A permissividade elétrica das cerâmicas, estudada por espectroscopia de impedância, apresentou temperatura de Curie em torno de $390^{\circ} \mathrm{C}$. As curvas da histerese ferroelétrica revelaram que a polarização remanescente é de $3,2 \mu \mathrm{C} / \mathrm{cm}^{2}$ e o campo coercitivo é de $10 \mathrm{kV} / \mathrm{cm}$ a $60 \mathrm{~Hz}$. Todos os resultados e caracterizações mostraram que as amostras de PZT obtidas com a via polimérica são eficientes como as preparadas no protocolo SSR convencional. 
Palavras-chave: Pó namométrico PZT, Sinterização em baixa temperatura, Propriedades dielétricas, Histerese ferroelétrica.

\section{INTRODUCTION}

The specific composition of the $\mathrm{Pb}\left(\mathrm{Zr}_{1-\mathrm{x}} \mathrm{Ti}_{\mathrm{x}}\right) \mathrm{O}_{3}$ solid solution - PZT52/48, close to the morphotropic phase boundary (MPB), has shown an enormous technological importance due to high performance in its ferro-, piro- and piezoelectric properties [1-4]. And the most common applications for PZT ceramics are high performance capacitors, ultrasonic generators, sensors of pressure and stress, non-volatile memories (FRAM), infrared detectors and electro optic devices [5-8].

The conventional sintering process of those ceramics uses powders prepared by solid state reaction (SSR) and requires high sintering temperatures $\left(1200-1300^{\circ} \mathrm{C}\right)$. At this range of temperature $\mathrm{PbO}$ volatilization results in the degradation of electrical properties and causes environmental pollution $[9,10]$. In addition, the high sintering temperatures also limit the choice of electrodes for multilayer systems to noble metals as platinum or palladium. Many efforts have been made to replace precious metals with less expensive metals, such as silver, nickel, or copper [11-13]. Nevertheless, in order to be able to use these metals, the sintering temperature of PZT must be lowered.

In this context, others preparation methods have been employed to reduce temperature sintering of PZT ceramics since 1980's [11]. Under certain conditions, Mazumder and Sem [10] showed PZT $\mathrm{Pb}\left(\mathrm{Zr}_{0.52} \mathrm{Ti}_{0.48}\right) \mathrm{O}_{3}$ can be sintered at a temperature as low as $715^{\circ} \mathrm{C}$. They concluded that the dielectric and piezoelectric properties of the $\mathrm{LiBiO}_{2}(\mathrm{LBO})$ added sintered samples were on a par and in some cases better than those of high-temperature conventionally sintered PZT without addition of LBO [12]. Other works have confirmed that sintering temperature of PZT ceramics can be lowered by adding various sintering aids with different oxides and excess $\mathrm{PbO}$, as mentioned by Sangawaret al [13]. However, others studies have shown that the sintering aids frequently worsen the electric properties [10-13]. Abreu et al. [14] synthesized PZT52/48 ceramic by a chemical method. They treated the powder at 400, 500, 600, 700 and $800^{\circ} \mathrm{C}$ for $2 \mathrm{~h}$. Those authors concluded that the modified Pechini method leads to homogeneous sub-micrometric spherical particles.

Alternatively, fine powders obtained through different methods of preparation such as hydrothermal synthesis [15], co-precipitation [16-20], pulsed wire discharge [21] and sol-gel [22-24] are effective in lowering the sintering temperatures $\left(800-1000{ }^{\circ} \mathrm{C}\right)$ due to their high reactivity and specific surface area. Even though there were many improvements made in this field, the heat treatments of PZT ceramics are still at higher sintering temperature [13].

In the present study, we present an alternative route for sintering PZT52/48 ceramics in temperatures as low as $900^{\circ} \mathrm{C}$ by using the polymeric precursor method, named Pechini method [25]. The advantage of this process is that it is not expensive and by microscopy analysis it is possible to discern in the obtained micrometer-scale aggregates extremely small particles of 20-100 nm. We also report ceramic with high densification and XRD patterns providing indication of only PZT52/48 formation. To verify the efficiency of the ceramic samples and their ferroelectric behavior, electrical characterization was carried out.

\section{MATERIAL AND METHODS}

\subsection{Pechini Method}

The powder of $\mathrm{Pb}\left(\mathrm{Zr}_{0.52} \mathrm{Ti}_{0.48}\right) \mathrm{O}_{3}$ was prepared using a modified Pechini method.Preparation of the solution was performed with a molar ratio of $1 \mathrm{~mol}$ of metallic cations to $4 \mathrm{~mol}$ of citric acid. The route is summarized in Figure 1.

Firstly, Titanium isopropoxide - Ti $\left[\mathrm{OCH}\left(\mathrm{CH}_{3}\right)_{2}\right]_{4}(\mathrm{Alfa}$ Aesar 97\%) - was dissolved in citric acid $\left(\mathrm{C}_{6} \mathrm{H}_{8} \mathrm{O}_{7}\right)$ aqueous solution at $100^{\circ} \mathrm{C}$ under stirring. The nominal quantity (in mass) of Ti (IV) within that solution was determined through a gravimetric procedure and found to be $2.6 \%$ of Ti(IV). The other two precursors were Zirconium (IV) oxide di-nitrate mono-hydrate - $\mathrm{ZrO}\left(\mathrm{NO}_{3}\right)_{2} \cdot \mathrm{H}_{2} \mathrm{O}$ (Alfa Aesar 99.9\%) - and Lead(II) acetate tri-hydrate $-\mathrm{Pb}\left(\mathrm{CH}_{3} \mathrm{COO}\right)_{2} \cdot 3\left(\mathrm{H}_{2} \mathrm{O}\right)$ (Merck) - both dissolved in water. The final citric acid aqueous solution was prepared with the addition order observing the electronegativity of the metallic cations $(\mathrm{Zr}, \mathrm{Pb}, \mathrm{Ti})$. The $\mathrm{pH}$ of the PZT solution was adjusted to 10 by using ammonium hydroxide $\left(\mathrm{NH}_{4} \mathrm{OH}\right)$. After that, ethylene glycol $\left(\mathrm{HOCH}_{2} \mathrm{CH}_{2} \mathrm{OH}\right)$ was added with a mass proportion of $40 \%$ of ethyleneglycol to $60 \%$ of citric acid. In order to facilitate the polymerization, the temperature was raised to $150{ }^{\circ} \mathrm{C}$ for 15 minutes.

PZT precursor (resin material) was submitted to two heat treatment in order to eliminate the organic 
part and to crystallize the precursor material. The thermal decomposition was carried out by heating the viscous solution up to $400{ }^{\circ} \mathrm{C}$ for 4 hours with a heat rate of $10{ }^{\circ} \mathrm{C} / \mathrm{min}$. The resulting material washeated up to $700^{\circ} \mathrm{C}$ with a heat rate of $20^{\circ} \mathrm{C} / \mathrm{min}$. This calcination temperature was determined by Thermal Gravimetric Analysis (TGA ) and differential thermal analysis (DTA) (Netzsch TG 209) where indicated the temperature of maximum mass loss, the decomposition kinetics and crystallization process. In order to reduce the powder agglomeration, a conventional milling in isopropyl alcohol was carried out for 24 hours and dried at $140{ }^{\circ} \mathrm{C}$.

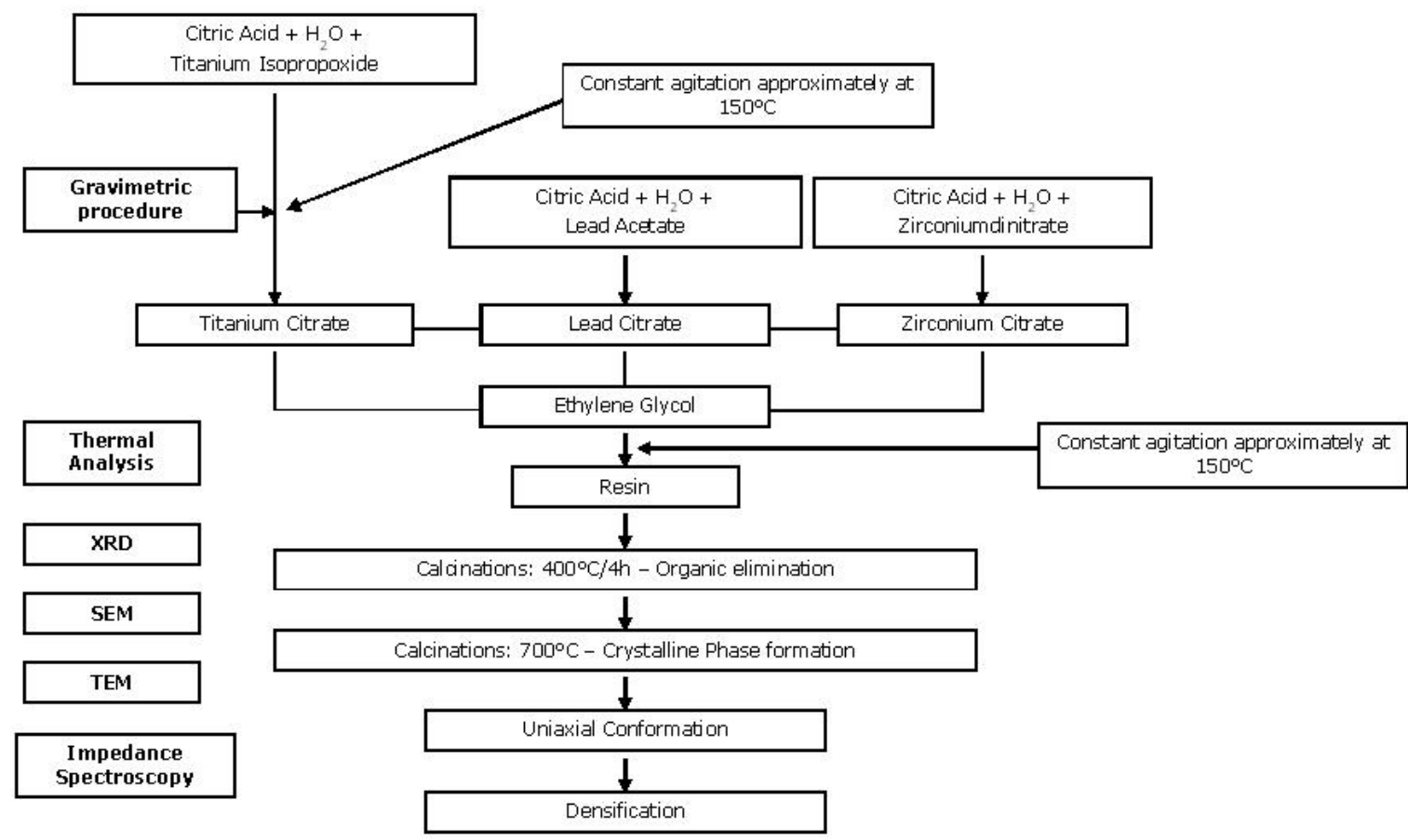

Figure 1: Scheme for PZT52/48 ceramic preparation via Pechini method.

\subsection{Ceramic preparation}

In order to compare to the Pechini method, we also prepared a PZT ceramic by solid state reaction process. We have used the same parameters for conformation and sintering, but the final sintering temperature was $1200{ }^{\circ} \mathrm{C}$. The density obtained for that ceramic was $95 \%$ of its theoretical density.

To determine the ideal sintering temperature of our ceramic samples (Pechini method), the dilatometry tests were performed. The precursor material was then pelletized and submitted to dilatometric analysis (DilNetzsch $402 \mathrm{EP}$ ) from $100^{\circ} \mathrm{C}$ up to $1250^{\circ} \mathrm{C}$. The results indicated that the maximum retraction at $900^{\circ} \mathrm{C}$. In order to make the cylindrical pellets with $6 \mathrm{~mm}$ of diameter, the powders were pressed uniaxially $(100$ $\mathrm{kgf} / \mathrm{cm}^{2}$ ) for 30 seconds. During sintering, the pellets were put in a crucible closed with a paste of Lead zirconate (PZ) powder and PVAL (Polyvinyl alcohol). PZ powder was also used as an atmosphere buffer.Sintering was carried out by means of an electrical furnace at $900{ }^{\circ} \mathrm{C}$ for 2 hours.

\subsection{Characterizations}

The ceramic samples were characterized by X-ray diffraction (XRD) using a diffractometer Rigaku Rotaflex RU200B, with $\mathrm{CuK} \alpha$ radiation $(\lambda=1.5406 \AA)$ and $2 \theta=20-70^{\circ}$, at room temperature. The density of the ceramics was determined by the Archimedes method, where the volume of a ceramic can be acquired by measuring buoyancy of the solid when immersed in liquid of known density (distilled water).Further, the absolute density can be calculated by the expression $\rho_{C}=M_{S} / M_{U}-M_{S U S}\left(\rho_{H 2 O}\right)$, where $\rho_{C}$ is absolute density, $M_{S}$ is the ceramic sample mass dried, $M_{U}$ is the ceramic sample mass wet, $M_{S U S}$ is the ceramic sample mass suspended and $\rho_{\mathrm{H} 2 \mathrm{O}}$ is water density. Analyses of the microstructure and to determine the distribution of mean particles size of the powder were performed with Field Emission Gun (FEG-SEM; Zeiss Supra 35-VP) and 
Transmission Electronic Microscopy (TEM; Philips CM 120). Scanning Electronic Microscopy images and EDX Analysis (SEM; Zeiss DSM960) were used to obtain the mean grain size of the ceramics (linear intercept method) and estimate lead volatilization. The electrical characterization was carried out by means of an impedance analyzer (Solartron SI 1260) at different frequencies of $\left(10^{2}-10^{6} \mathrm{~Hz}\right)$ with an applied voltage of 1 Volt AC. The range of temperature was from room temperature to $550^{\circ} \mathrm{C}$ with a heating/cooling rate of 2 ${ }^{\circ} \mathrm{C} /$ min. The ferroelectric hysteresis measurements at $60 \mathrm{~Hz}$ were carried out with a homemade modified Sawyer-Tower circuit [25-31].

\section{RESULTS ANDDISCUSSIONS}

\subsection{Synthesis and powder characteristics}

The thermo gravimetric analysis (TGA) and differential thermal analysis (DTA) of the PZT powders were carried out in air atmosphere with the heating rate of $10{ }^{\circ} \mathrm{C} / \mathrm{min}$ and the TGA and DTA for PZT 52/48 is shown in Figure 2. TG curves can be observed that the thermal decomposition of each gel occurs with different mechanisms. From room temperature to $100{ }^{\circ} \mathrm{C}$, the weight loss can be attributed to free water. From 310 to $400{ }^{\circ} \mathrm{C}$ the thermal events can be attributed to the elimination of water resultant from the ester formed between the citric acid and ethylene glycol and free citrate. It is possible to verify that the complete elimination of organic matter occurs after $600{ }^{\circ}$ Cindicatesthat PZT52/48 was crystallized, after complete removal of organic matter. The DTA curves are in conformity with these observations. There is one exothermic peakin DTA curve at $310{ }^{\circ} \mathrm{C}$. The peak may be corresponding to the combustion of most of the organic species entrapped in PZT 52/48.

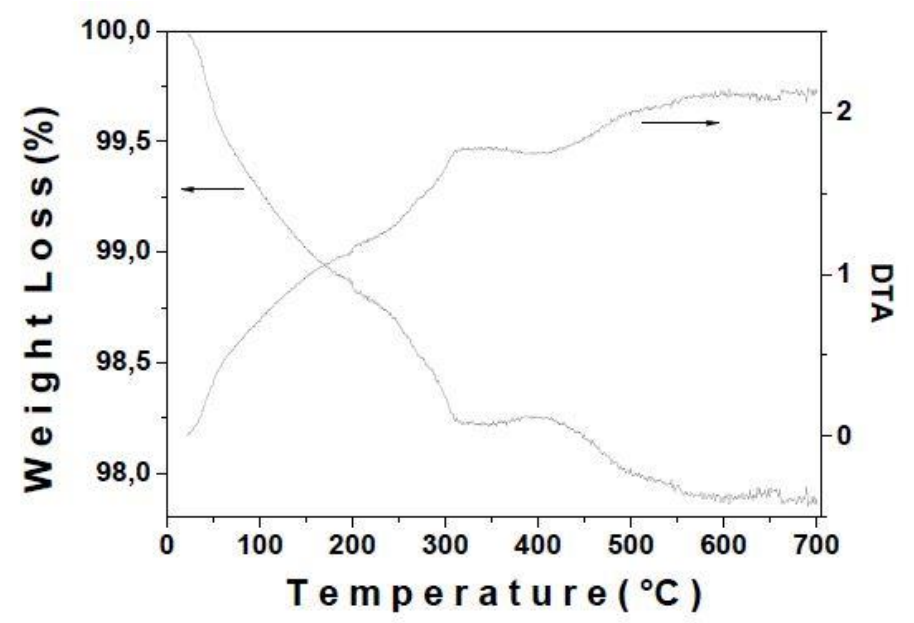

Figure 2: The thermo gravimetric analysis (TGA) and differential thermal analysis (DTA) measurements of PZT52/48 powders.

The X-ray patterns for different methods are shown in Figure 3. It can be observed that the PZT crystallization process occurs toboththemethods. The PZT52/48 precursors prepared at $400{ }^{\circ} \mathrm{C}, 700{ }^{\circ} \mathrm{C}$ and $900{ }^{\circ} \mathrm{C}$, were then analyzed by X-ray powder diffraction (XRD) to evaluate crystalline phase formations. The $\mathrm{X}$-ray patterns results of the precursors are displayed in Figure 3(a). It is possible to observe that peaks are indexed to PZT52/48 samples at $700^{\circ} \mathrm{C}$ and $900{ }^{\circ} \mathrm{C}$ without any formation of secondary phase. In the sample at $400{ }^{\circ} \mathrm{C}$ the formation of the crystalline phase is not complete. The results corroborate with the TGA and DTA. Thus, Pechini method confirms to be a good design of the used calcination process. After heat treatment at $700^{\circ} \mathrm{C}$ for 2 hours, the powder already showed the typical peaks of the desired phase, but still with pseudo-cubic characteristics. Such effect of a pseudo-cubic aspect is due to Pechini method to originate nanometric particles. The XRD patterns of PZT ceramic sintered at $900{ }^{\circ} \mathrm{C}$ for $2 \mathrm{~h}$ is also shown in Figure 3a. The profile show sharp diffraction peaks, which indicate single perovskite phase, better homogeneity and crystallization of the sample. PZTSSR, sintered at $1200{ }^{\circ} \mathrm{C}$, is shown in Figure 3(b). It can be observed that this sample does not exhibit any formation of crystallized secondary phase at tetragonal structure. 

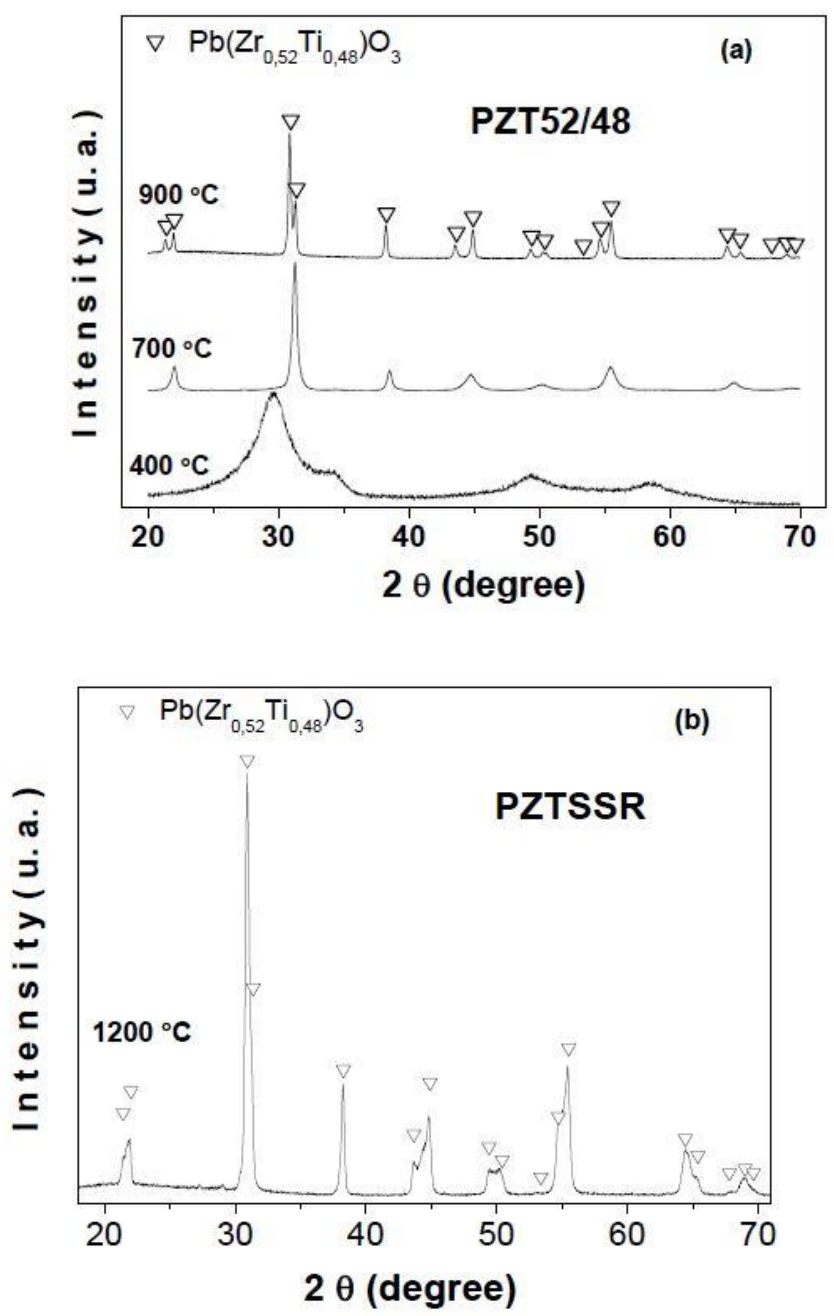

Figure 3: XDR patterns of PZT52/48 synthesized by Pechini method samples powders at $400{ }^{\circ} \mathrm{C}, 700^{\circ} \mathrm{C}$, $900{ }^{\circ} \mathrm{C}$ for and PZTSSR at $1200{ }^{\circ} \mathrm{C}$.

In order to provide a detailed view of microstructure and size distribution of the particles, SEM-FEG and TEM microscopy of the powder were carried out.Figure $4 \mathrm{a}$ shows the strong coalescence within the powder after the heat treatment at $700{ }^{\circ} \mathrm{C}$.In order to break those agglomerates, a conventional milling for 24 hours using Zirconium spheres with $1 \mathrm{~mm}$ of diameter and isopropyl alcohol was carried out. After that, the sample was analyzed by SEM and TEM microscopes.

Details of the PZT ceramic grain morphology can be observed in the SEM image in Figure $4 \mathrm{~b}$. The analysis of the figure indicates that the milling was effective to down size those agglomerates. Moreover, TEM micrograph (Figure 4c) reveals the particles have size lower than $100 \mathrm{~nm}$. This result has favored to densification of PZT ceramic. 

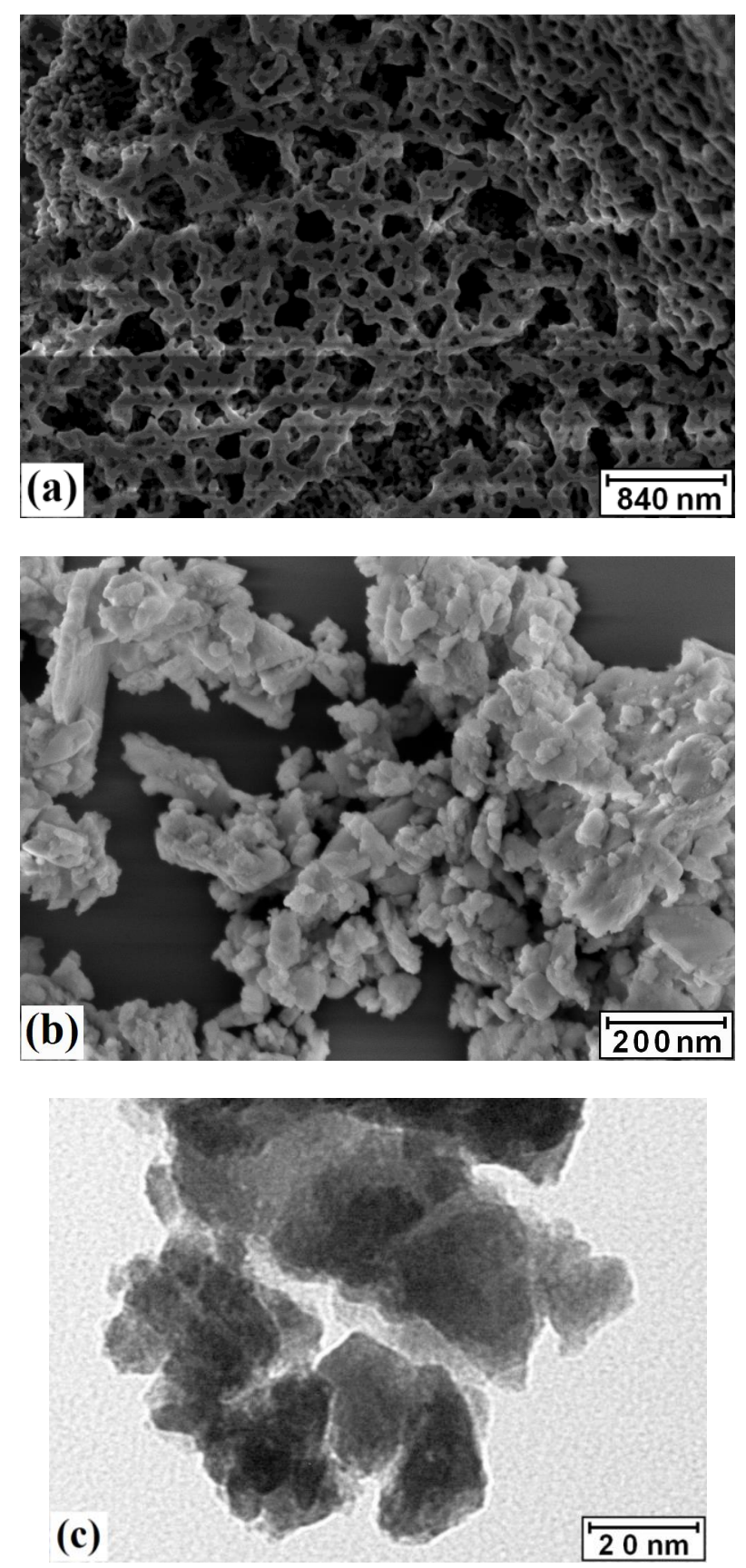

Figure 4: Microscopy images of the powders FEG(a) before milling, FEG(b) and TEM(c) after milling.

\subsection{Sintering procedure}

To determine the ideal sintering temperature of our ceramic samples prepared by the Pechini method, the dilatometry tests were performed. The dilatometric analysis was carried out at a heating rate of $5^{\circ} \mathrm{C} / \mathrm{min}$ in air atmosphere. In order to perform this experiment, a cylindrical sample with $7.0 \mathrm{~mm}$ of diameter was prepared.With a uniaxial compression of $80 \mathrm{kgf} / \mathrm{cm}^{2}$ for 20 seconds, we obtained a ceramic sample with green density of $\sim 43 \%$, obtained by geometric method, of its theoretical density ( $\rho=8.006 \mathrm{~g} / \mathrm{cm}^{3}$ - card \#330784; JCPDS). The temperature where the maximum retraction takes place was found to be $896{ }^{\circ} \mathrm{C}$ (Figure 5). 


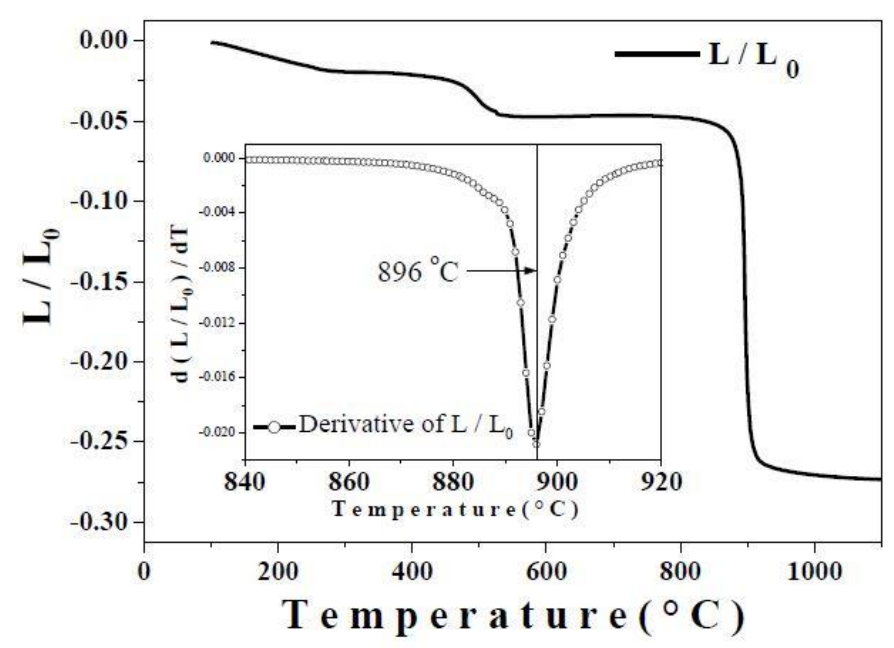

Figure 5: Normalized dilatometric curve $\left(\mathrm{L} / \mathrm{L}_{0}\right)$ for PZT52/48 sample.The inset shows the derivative of $\mathrm{L} / \mathrm{L}_{0}$ with evidence of a maximum retraction peak at $896^{\circ} \mathrm{C}$.

In order to reduce the powder agglomeration after conventional milling in isopropyl alcohol was carried out drying at $140{ }^{\circ} \mathrm{C}$. In this process, sieve $(5 \mu \mathrm{m})$ and mortar were used.

The sintering process was done at $900^{\circ} \mathrm{C}$ for $2 \mathrm{~h}$ and resulted in high density ceramic with $96 \%$ of its theoretical density. In the figure $3\left(900^{\circ} \mathrm{C}\right)$ XRD results suggest that PZT52/48 ceramic changes from a pseudo-cubic aspect to a tetragonal crystal system.

The SEM and optical images of PZT52/48 and PZTSSR, sintered at $900{ }^{\circ} \mathrm{C}(5000 \mathrm{X}$ magnification) and $1200{ }^{\circ} \mathrm{C}$ (500X magnification) are shown in Figure 6, respectively. The grain size of the samples is measured by linear intercept method [23]. The average grain size is found by dividing the number of intersections by the actual line length. From the micrographs on Figure 6, the grain size of PZTSSR sample is $(3.53 \pm 0.05) \mu \mathrm{m}$, while the grain size of PZT52/48 sample is $(1.31 \pm 0.05) \mu \mathrm{m}$. This indicates that the grainsize distribution is affected by sintering procedure. The microstructure also suggests the role about the densification of the ceramics at low sintering temperature without affecting the phase formation, and lattice structure as revealed in the XRD. Further, the sintered aid sample with nano grains showed significant improvement in dielectric properties at low sintering temperature as compared to conventionally sintered PZT ceramics.

The semi-quantitative analysis by EDX showed a slight loss of lead during the ceramic preparation. Table 1 presents the EDX (PZT52/48) analysis for a single grain and for a general view containing several grains. It is possible to assume the following final composition for PZT52/48 ceramics: $\mathrm{Pb}_{0,9698}\left(\mathrm{Zr}_{0,5584} \mathrm{Ti}_{0,4718}\right) \mathrm{O}_{3} \rightarrow \mathrm{Pb}\left(\mathrm{Zr}_{0,5420} \mathrm{Ti}_{0,4580}\right) \mathrm{O}_{3}$, which is close to the PZT52/48 composition, also this results is in agreement with XRD analysis. 

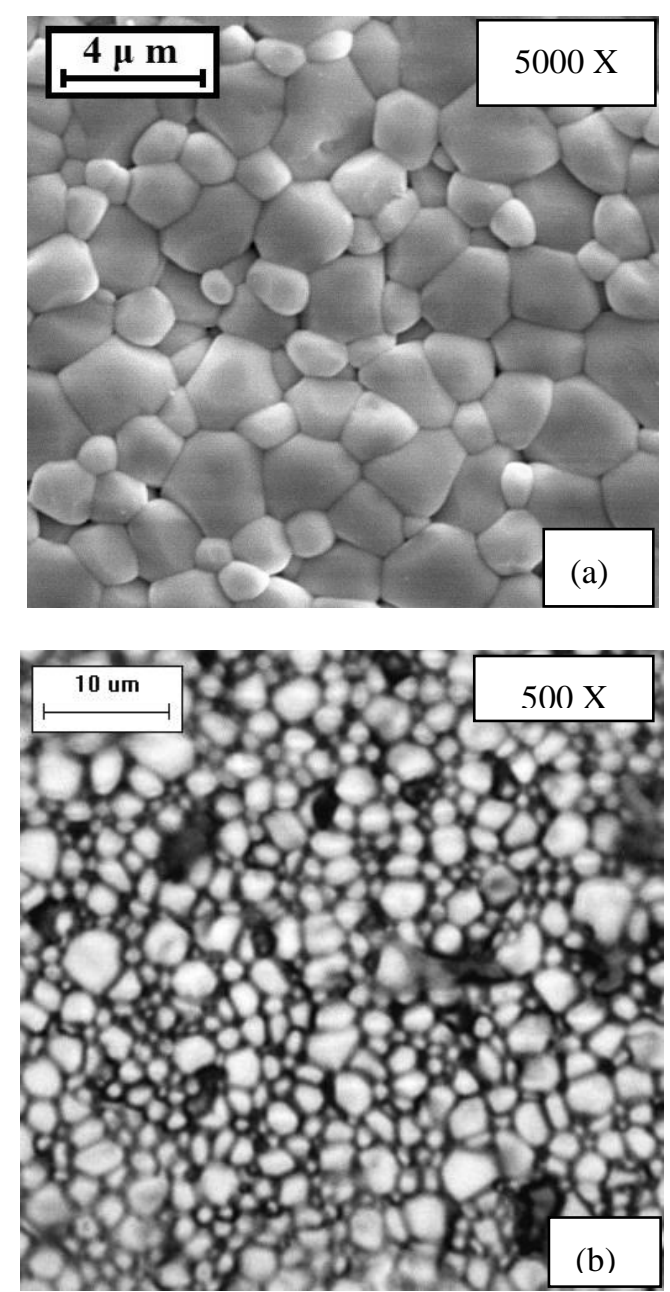

Figure 6: SEM image illustrating the microstructure of a ceramic sample of PZT52/48(a) and optical image of PZTSSR(b).

Table 1: Compositional analysis by EDX Experimental (single grain and general view) and theoretical values for $\mathrm{Pb}, \mathrm{Zr}$ and $\mathrm{Ti}$ elements (PZT52/48).

\begin{tabular}{lllllll}
\hline & \multicolumn{2}{l}{ Grain composition } & \multicolumn{2}{l}{ General view } & \multicolumn{2}{l}{ Theoretical quantities } \\
\cline { 2 - 7 } & Element \% & Atomic $\%$ & Element \% & Atomic \% & Element \% & Atomic \% \\
\hline \hline $\mathrm{Pb} \mathrm{M}$ & 73.04 & 48.25 & 73.38 & 48.73 & 74.64 & 50.00 \\
$\mathrm{Zr} \mathrm{L}$ & 18.65 & 27.99 & 18.46 & 27.85 & 17.09 & 26.00 \\
$\mathrm{Ti} \mathrm{K}$ & 8.31 & 23.76 & 8.15 & 23.42 & 8.27 & 24.00 \\
\hline \hline Total & 100.00 & 100.00 & 100.00 & 100.00 & 100.00 & 100.00 \\
\hline
\end{tabular}

Compared to the conventional ceramic preparationmethods $[5,6]$, the sintering temperature reduced in $300{ }^{\circ} \mathrm{C}$. The resultant ceramics presents low chemical fluctuations despite being sintered at very low temperature, showing their high degree of reactivity. The lead volatilization and creation of defects, such as $\mathrm{Pb}^{2+}$ and $\mathrm{O}^{2-}$, are significantly reduced and keep the PZT stoichiometry near to the morphotropic phase boundary. For PZTSSR ceramics compositional analysis by EDX was not performed due to the XRD patterns of the sample shows the desired PZT phase. 


\subsection{Electrical properties}

The ferroelectricity of the sample was investigated with different frequencies. The Figure 7 shows only the results of PZT52/48 ceramic. The behavior revealed a peculiar ferrelectric-paraeletric phase transition around $390{ }^{\circ} \mathrm{C}$ (Curie temperature, $\mathrm{T}_{\mathrm{C}}$ ) for samples in the maximum permittivity. The peak position shows no frequency dependence to higher frequencies $\left(10^{4}, 10^{5}\right.$ and $\left.10^{6} \mathrm{~Hz}\right)$. For low frequencies $\left(10^{2}\right.$ and $\left.10^{3} \mathrm{~Hz}\right)$, it is possible to observe the phenomenon dielectric anomaly which is also found in the literature $[24,25]$. Moreover, in Figure 7 the loss factor $\left(\tan \delta=\varepsilon^{\prime \prime} / \varepsilon^{\prime}\right)$ is also depicted showing very low values $(\sim 0.01)$ around room temperature. All results of electrical measurements are summarized on Table 2 of the two ceramics, the one prepared by polymeric precursor method and by solid state reaction.

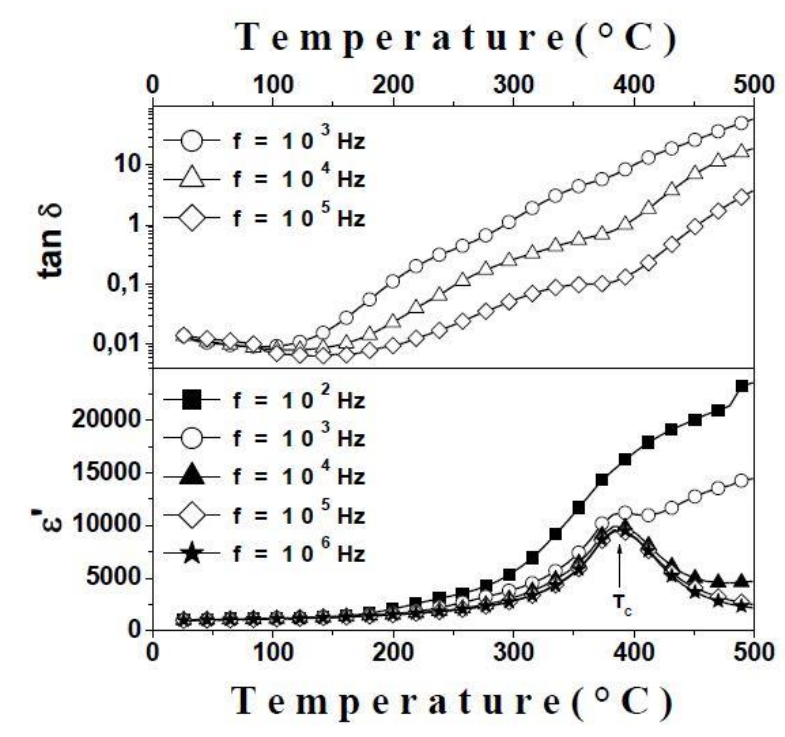

Figure 7: Temperature dependence of dielectric constant and loss factor $(\tan \delta=\varepsilon " / \varepsilon ')$ at several frequencies to PZT52/48.

We observed that the density of PZT52/48 sample is slightly higher than PZTSSR sample. It can be attributed to the increase in the number of oxygen vacancy concentration, the number of lead vacancy concentration, vaporization of oxides and additives on sample prepared at high sintering temperatures. It is also observed from the Table 2, that Curie temperature increases with a decreasing sintering temperature. Furthermore, the dielectric constant in room temperature is also higher than PZTSSR ceramics sintered at $1200{ }^{\circ} \mathrm{C}$. This may be attributed to finer grain size.

Table 2: Comparison between properties of PZT ceramics produced via polymeric precursors and solid state reactions.

\begin{tabular}{lllllllll}
\hline \multirow{2}{*}{ Sample } & $\begin{array}{l}\mathrm{T}_{\text {sintering }} \\
\left({ }^{\circ} \mathrm{C}\right)\end{array}$ & $\begin{array}{l}\rho_{\text {Relative }} \\
(\%)\end{array}$ & $\begin{array}{l}\rho_{\text {Absolut }} \\
\left(\mathrm{g} / \mathrm{cm}^{3}\right)\end{array}$ & $\begin{array}{l}\mathrm{T}_{\mathrm{C}}\left({ }^{\circ} \mathrm{C}\right) \\
10^{4} \mathrm{~Hz}\end{array}$ & $\begin{array}{l}\varepsilon^{\prime}(\text { Troom }) \\
10^{4} \mathrm{~Hz}\end{array}$ & $\begin{array}{l}\varepsilon^{\prime}\left(\mathrm{T}_{\mathrm{C}}\right) \\
10^{4} \mathrm{~Hz}\end{array}$ & $\begin{array}{l}\mathrm{P}_{\mathrm{R}} \\
\left(\mu \mathrm{C} / \mathrm{cm}^{2}\right)\end{array}$ & $\begin{array}{l}\mathrm{P}_{\mathrm{S}} \\
\left(\mu \mathrm{C} / \mathrm{cm}^{2}\right)\end{array}$ \\
\hline PZT52/48 & 900 & $96 \pm 1$ & 7.68 & $387 \pm 1$ & 990 & 9993 & 3.2 & 4.20 \\
PZTSSR & 1200 & $95 \pm 1$ & 7.60 & $378 \pm 1$ & 910 & 8590 & 3.8 & 5.02 \\
\hline
\end{tabular}

Polarization-electric field of our samples is displayed on Figure 8. The PZT52/48 sample showed remnant polarization $\left(\mathrm{P}_{\mathrm{R}}\right)$ equal to $3.2 \mu \mathrm{C} / \mathrm{cm}^{2}$, while PZTSSR sample a value of $3.8 \mu \mathrm{C} / \mathrm{cm}^{2}$. The ferroelectric properties are strongly influenced by composition, grain size, defects, external field and orientation of domains. The PZT52/48 ceramic has domain structure more dense and uniform due has a lower grain size that the PZTSSR. It may explain lower remnant polarization for PZT52/48 samples.

The coercive field $(10 \mathrm{kV} / \mathrm{cm})$ showed no differences for the both materials. Although both materials showed comparable values of coercive field, remnant polarizations, it is worth mentioning that the PZTSSR sample presented a more squared hysteresis loop. This is a consequence of its bigger mean grain size $(\sim 3 \mu \mathrm{m})$. It is possible to observe in both the samples presented to reach a good saturation polarization $\left(\mathrm{P}_{\mathrm{R}}\right)$ with values 
to PZTSSR of $5.02 \mu \mathrm{C} / \mathrm{cm}^{2}$ and PZT52/48 of $4.20 \mu \mathrm{C} / \mathrm{cm}^{2}$.

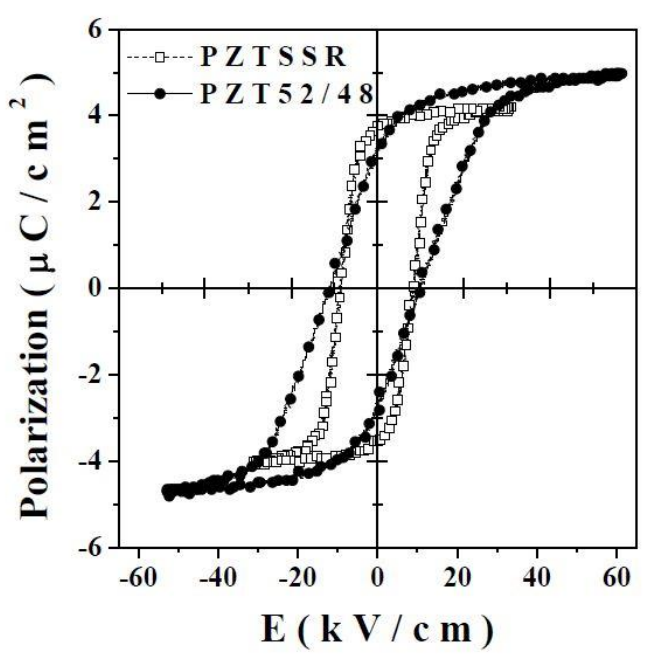

Figure 8: Hysteresis loops at room temperature of ceramics prepared with powders by conventional SSR (Solid State Reaction) and Pechini Method.

As compared with the sintering temperatures obtained in previous studies [10-19], which used different methods of preparation and several additives to facilitate the sintering process, the route described herein is an attractive option.

\section{CONCLUSIONS}

Ceramics of PZT52/48 were sintered at temperature lower than $900{ }^{\circ} \mathrm{C}$ by the polymeric precursor synthesis. The reduction of more than $300^{\circ} \mathrm{C}$ in PZT sintering probably reduces the lead volatilization, as well as helps to keep the PZT stoichiometry near the morphotropic phase boundary, avoid the environmental pollution and save energy cost. The electrical properties, dielectric constant and ferroelectric hysteresis, were compared with the ones of a ceramic obtained by conventional solid state reaction and found to be similar in magnitude. The results indicate that modified Pechini method represent a good option to synthesis materials PZT-based.

\section{ACKNOWLEDGEMNT}

The authors gratefully acknowledge financial supports from CAPES, Brazilian research-funding agencies, and the Instituto de Física de São Carlos, Universidade de São Paulo.

\section{BIBLIOGRAPHY}

[1] JAFFE, B., COOK, W.R.; JAFFE, H. Piezoelectric Ceramics. [S.1.]: Academic Press, 1971.

[2]HAERTLING, G.H. Ferroelectrics ceramics: history and technology. Journal of the American Ceramic Society, v. 82, n. 4, pp. 797-818, 1999.

[3] YAMASHITA, K.,et al. Ultrasonic micro array sensors using piezoelectric thin films and resonant frequency tuning. Sensor and Actuators A: Physical, v. 114, n. 2-3, pp. 147-153, 2004.

[4]KIM, K., LEE, S. Integration of lead zirconium titanate thin films for high density ferroelectric random access memory. Journal of Applied Physics, v. 100, n. 5, pp. 51604-51611, 2006.

[5]BUCKNER, D.A., WILCOX, P.D. Effect of calcining on sintering of lead zirconate-titanate ceramics. American Ceramic Society Bulletin, v. 51, n. 3, pp. 218-222, 1972.

[6]WEBSTER, A. H.; WESTON, T. B.; BRIGHT, Norman FH. Effect of PbO deficiency on the piezoelectric properties of lead zirconate- titanate ceramics. Journal of the American Ceramic Society, v. 50, n. 9, p. 490491, 1967.

[7]CRUSM, A.T.,HALLORAN, J.W. Fabrication of microconfigured multicomponent ceramics. Journal of the American Ceramic Society, v. 81, n. 4, pp. 1053-1057, 1998.

[8]LEE, Wen- Hsi; TSENG, Tseung-Yuen; HENNINGS, Detlev FK. Effects of calcination temperature and $\mathrm{A} / \mathrm{B}$ ratio on the dielectric properties of $(\mathrm{Ba}, \mathrm{Ca})(\mathrm{Ti}, \mathrm{Zr}, \mathrm{Mn}) \mathrm{O} 3$ for multilayer ceramic capacitors with nickel electrodes. Journal of the American Ceramic Society, v. 83, n. 6, p. 1402-1406, 2000. 
[9] ZUO, R.,et al. Effects of additives on the interfacial microstructure of cofired electrode-ceramic multilayer systems. Journal of the American Ceramic Society, v. 85, n. 4, pp. 787-793, 2002.

[10] MAZUMDER, R., SEM, A. 'Ultra'-low-temperature sintering of PZT: a synergy of nano-powder synthesis and addition of a sintering aid. Journal of the European Ceramic Society, v. 28, n. 14, pp. 27312737, 2008.

[11] TAKAHASHI, S. Sintering $\mathrm{Pb}(\mathrm{Zr}, \mathrm{Ti}) \mathrm{O} 3$ ceramics at low temperature. Japanese Journal of Applied Physics, v. 19, n. 4, pp. 771-772, 1980.

[12] DONG, D.,et al. Lowering of sintering temperature of $\mathrm{Pb}(\mathrm{Zr}, \mathrm{Ti}) \mathrm{O} 3$ ceramics by the addition of $\mathrm{BiFeO} 3$ and $\mathrm{Ba}(\mathrm{Cu} 0.5 \mathrm{~W} 0.5) \mathrm{O}$. Ferroelectrics, v. 145, n. 1, pp. 125-133, 1993.

[13] SANGAWAR, S.R., PRAVEENKUMAR, B. Structural and electrical properties of low temperature sintered PZT ceramics. Ferroelectrics, v. 517, n. 1, pp. 66-74, 2017.

[14] JR., A.A.,et al. Effect of urea on lead zirconate titanate- $\mathrm{Pb}(\mathrm{Zr} 0.52 \mathrm{Ti0} 0.48) \mathrm{O} 3$-nanopowders synthesized by the Pechini method. Journal of the European Ceramic Society, v. 25, n. 5, pp. 743-748, 2005.

[15] MANDOKI, N.T.,et al. Hydrothermal synthesis of doped PZT powders: sintering and ceramic properties. Materials Letters, v. 58, n. 20, pp. 2489-2493, 2004.

[16] GAJBHIYE, N.S.,et al. Characterization of nanostructured PZT prepared by chemical routes. Journal of nanoscience and nanotechnology, v. 7, n. 6, pp. 1975-1979, 2007.

[17] MOHANA RAO, K.R., PRASADA RAO, A.V., KOMAMENI, S. Reactive PZT precursor powder by coprecipitation. Materials Letters, v. 28, pp. 463-467, 1996.

[18] BRUNO, A.M., EIRAS, J.A. Preparation of coprecipitated ferroelectric ceramic powders by two-stage calcination. Journal of American Ceramic Society, v. 76, pp. 2734-2736, 1993.

[19] FANG, Jiye et al. Synthesis and characterization of ultrafine lead zirconate powders. Ceramics international, v. 24, n. 7, p. 507-513, 1998.

[20] KINEMUCHI, Yoshiaki et al. Synthesis of nanosize PZT powders by pulsed wire discharge. IEEE transactions on plasma science, v. 30, n. 5, p. 1858-1862, 2002.

[21] HIRASHIMA, Hiroshi; ONISHI, Eiji; NAKAGAWA, Michihiro. Preparation of PZT powders from metal alkoxides. Journal of non-crystalline solids, v. 121, n. 1-3, p. 404-406, 1990.

[22] LIU, Chao et al. Sol- gel synthesis of free-standing ferroelectric lead zirconate titanate nanoparticles. Journal of the American Chemical Society, v. 123, n. 18, p. 4344-4345, 2001.

[23] DURAN, P., MOURE, C. Sintering at near theoretical density and properties of PZT ceramics chemically prepared. Journal of Materials Science, v. 20, n. 3, pp. 827-833, 1985.

[24] PECHINI, M.U. 3330697, 1967.

[25] SAWYER, Charles Baldwin; TOWER, C. H. Rochelle salt as a dielectric.Physical review, v. 35, n. 3, p. $269,1930$.

[26] MENDELSON, M.I. Average grain size in the polycrystalline ceramics. Journal of the American Ceramic Society, v. 52, n. 8, pp. 443-446, 1969.

[27] ZHAO, Z.,et al. Grain-size effects on the ferroelectric behavior of dense nanocrystalline BaTiO3 ceramics. Physical Review B, v. 70, n. 2, pp. 024107, 2004.

[28] JIANG, Q., CUI, X.F., ZHAO, M. Size effects on Curie temperature of ferroelectric particles. Applied Physics A, v. 78, n. 5, pp. 703-704, 2004.

[29] DU, Z.et al. Effect of $\mathrm{MnCO} 3$ on the electrical properties of PZT-based piezoceramics sintered at low temperature. Journal of Alloys and Compounds, v. 801, pp. 27-32, 2019.

[30] HAN, B.,et al. Temperature-insensitive piezoelectric performance in $\mathrm{Pb}$ (Zr0. 52Ti0. 42Sn0. 02Nb0. 04) O3 ceramics prepared by spark plasma sintering. ACS applied materials \& interfaces, v. 9, n. 39, pp. 3407834084, 2017.

[31] OLIVEIRA, C.A.,et al.Synthesis and characterization of lead zirconate titanate (PZT) obtained by two chemical methods. Ceramics International, v. 40, n. 1, pp. 1717-1722, 2014

\section{ORCID}

Jaime Alberto Sanchez Caceres

Carlos Augusto Carlos Passos

João Victor Soares Chagas https://orcid.org/0000-0002-8233-9715

https://orcid.org/0000-0002-6303-3569

https://orcid.org/0000-0001-6472-0603 